\title{
More losers than winners in a century of future Southern Ocean seafloor warming
}

Huw J Griffiths*, Andrew JS Meijers, Thomas J Bracegirdle

British Antarctic Survey, Cambridge, UK hjg@bas.ac.uk

\begin{abstract}
The waters of the Southern Ocean are projected to warm over the coming century, with potential adverse consequences for native cold-adapted organisms. Warming waters have caused temperate marine species to shift their ranges poleward. The seafloor animals of the Southern Ocean shelf have long been isolated by the deep ocean surrounding Antarctica and the Antarctic Circumpolar Current, with little scope for southward migration. How these largely endemic species will react to future projected warming is unknown. By considering 963 invertebrate species, we show that within the current century, warming temperatures alone are unlikely to result in wholesale extinction or invasion affecting Antarctic seafloor life. However, 79\% of Antarctica's endemic species do face a significant reduction in suitable temperature habitat (an average 12\% reduction). Our findings highlight the species and regions most likely to respond significantly (negatively and positively) to warming and have important implications for future management of the region.
\end{abstract}

\section{Introduction}

When faced with warming ocean temperatures many marine species have been shown to exhibit poleward range shifts ${ }^{1-3}$. These range shifts are dependent on having available suitable habitat at higher (cooler) latitudes ${ }^{4}$. For polar organisms it could be said that they are at the end of the line, with limited options in terms of northwards or southwards migration ${ }^{4,5}$. Unlike the Northern Hemisphere, the route of poleward migration of benthic species in the Southern Hemisphere is punctuated by a lack of continuous continental shelf from $\sim 57^{\circ} \mathrm{S}$ to $\sim 60^{\circ} \mathrm{S}$, a sharp temperature gradient across the Subantarctic 
(SAF) and Polar Fronts (PF) and the strong eastward flow of the Antarctic Circumpolar Current (ACC), all of which serve to isolate Antarctica both oceanographically and biologically ${ }^{6,7}$.

Global projections for the response of marine organisms to climate change based upon pelagic species and/or sea surface temperature data show the Southern Ocean (south of the PF) to be a hotspot of species turnover, local extinction and invasion ${ }^{8,9}$ and a loss of species richness ${ }^{10}$. Benthic animals are, in terms of numbers of species, by far the richest component of Antarctic biodiversity ${ }^{11}$. The benthic animals of the Southern Ocean shelf have long been isolated from their northern neighbours ${ }^{6,7}$ and how these largely endemic species will react to future projected warming is unknown.

We project likely changes in the potential distribution of 963 shelf dwelling (water depth $<1,000 \mathrm{~m}$ ) benthic invertebrate species, represented by over 57000 occurrence records from south of $40{ }^{\circ} \mathrm{S}$, under projected seafloor temperatures in 2099 derived from an ensemble of coupled climate models forced by a strong carbon forcing scenario (RCP8. $5^{12}$ ) (Fig. 1). Our findings reveal the species and geographic areas most likely to respond (negatively and positively) to predicted warming of bottom water on the continental shelf and have important implications for future resource management in the region.

\section{Species distribution and projected change}

Georeferenced benthic species occurrence records were assigned the modelled present-day seafloor temperature (ensemble averaged over model means between 1976 and 2005, see Supplementary Table 1) for their location, and the thermal range of each species was calculated (maximum and minimum temperature values from their present-day known locations). Multivariate analyses of the modelled present day temperature ranges of all studied species resulted in 10 distinct groupings with similar distributions (see methods). Of these groupings four are Antarctic only, one is Antarctic and Subantarctic, two are Antarctic to temperate, one is limited to the Subantarctic and two are temperate only (Fig. 2). Each of these groupings will be affected differently by the projected increases in temperature. All analyses of potential distributions under projected temperatures were carried out using the pointwise mean of a 19 member model ensemble of seafloor temperatures (Supplementary Table 1) temporally averaged over 2070-2099 under the CMIP5 RCP8.5 forcing scenario (Fig. 3). To address 
the differences between models, particularly on the Antarctic shelf, we used a mean of the 19-member ensemble as well as examining the most extreme regional cases.

Temperature changes over the Antarctic and Subantarctic shelves showed warming in most regions, especially the West Antarctic Peninsula, the Kerguelen Plateau and parts of the Ross and Weddell Seas. The waters south of the PF are expected to warm by an average of $0.4^{\circ} \mathrm{C}\left( \pm 0.3^{\circ} \mathrm{C}\right)$, with a maximum regional mean projected increase of $2.15^{\circ} \mathrm{C}$ (Fig. 1).

Species found only in Antarctic bottom waters between $-1.8{ }^{\circ} \mathrm{C}$ and $\sim 1.2{ }^{\circ} \mathrm{C}$, Groups 8 to 10 , faced a projected reduction in suitable habitat (Fig. 2). Only the Antarctic endemic species that cannot tolerate sub-zero water, Group 7, increased in potential area. Species with geographic ranges crossing the PF, groups 4 to 6, experienced a warming at the upper limit of their extent, reducing their range, however the warming of cold Antarctic waters allowed for range expansion for some species south of the PF. These Antarctic species that cannot tolerate sub-zero water increased their potential range southwards and into East Antarctica.

Species currently only found north of the PF, Groups 1 to 3, are unable to cross into Antarctic waters, other than some species that are able to reach the warmer waters of the Kerguelen Plateau at a projected temperature range of between 3 and $5.8^{\circ} \mathrm{C}$ (compared with a present day range of 2.2 to $4.4^{\circ} \mathrm{C}$ ). Waters south of $60^{\circ} \mathrm{S}$ and the South Georgia shelf have not warmed sufficiently to provide suitable conditions for animals from north of the PF, reaching a maximum projected summer temperature of $\sim 2.6^{\circ} \mathrm{C}$ (Fig. 3). Present day (1976-2005) modelled mean minimum seafloor temperatures, shallower than 1,000 m, for southern South America are in the region of $3.8^{\circ} \mathrm{C}$.

Of the 963 benthic species analysed 577 are likely to experience a reduction in thermally suitable habitat with projected warming (Fig. 4). Of these, 398 (41\% of all species) are expected to experience a range loss of under $10 \%$ of their present-day suitable temperature potential habitat. $18.6 \%$ of species are projected to lose between 10 and $40 \%$ of their present day potential habitat.

The greatest predicted reduction in area is for a single species of echinoid, Sterechinus diadema (Group 3) - native to the Kerguelen Plateau and Crozet, projected to lose $\sim 43 \%$ of its present-day potential 
range. The majority (536) of the species losing potential habitat are found living south of the PF (308 of which are found only in Antarctic waters). $79 \%$ of species endemic to Antarctic waters are projected to experience a reduction in suitable habitat.

All 7 of the species projected to more than triple their potential range are from Group 7 and are native to South Georgia, at the northern limit of Antarctic waters, and currently experience a narrow temperature range of between 0.9 and $1.6^{\circ} \mathrm{C}$. However this projected increase in range is dependent upon these species being able to migrate across deep water to reach the Antarctic continental shelf to occupy suitable habitat because South Georgia is projected to warm beyond their current thermal range (Supplementary Figs. 1 and 2). Species with ranges that cross the PF are found to both lose (53.5\%) and gain (46.5\%) potential habitat. The majority (72.1\%) of non-Antarctic species included in the study showed a potential range expansion with warming, although it is unlikely that this study accurately represents the effects at the true northern limits of their ranges.

\section{Species turnover and regional change}

The projected changes in species distribution (assuming no adaptation to higher temperatures) will have an effect on regional and local species richness, with some areas increasing in diversity and others decreasing. Species turnover (Fig. 5) showed a projected overall reduction in species numbers in West Antarctica, the South Orkney Islands and South Georgia. This is due to temperatures reaching a threshold that excludes many cold water specialists from Antarctica (Groups 7-10) but are still not warm enough for more northerly species to colonise.

The projected loss of species in most of the more northerly regions (South America, New Zealand and Tasmania) is probably due to limitations of the data used in the analyses, as those data do not include species from further north, which are likely to spread southwards into these regions (north of the PF). The Weddell Sea, Ross Sea and parts of East Antarctica showed a projected increase in diversity. This is due to a slight increase in temperatures that favoured a greater number of Antarctic species (Groups 4-6) without excluding the cold water specialists (Groups 8-10).

\section{Regional upper bounds of warming}


Using the ensemble local maximum projected temperature increase for each pixel from the climate model ensemble to explore the (likely unphysical) upper bound of the warmest future scenario (Fig. 6) we saw significantly higher temperatures across the entire study region, with no one outlying model dominating everywhere. However, temperatures south of $60^{\circ} \mathrm{S}$ showed a lower anomaly (mean value of $1.13^{\circ} \mathrm{C}$ ) between the ensemble mean and maximum values than those further north (mean anomaly value of $4.19^{\circ} \mathrm{C}$ ). This extreme upper bound would allow species from north of the Polar Front to colonise South Georgia but would still not warm the waters south of $60{ }^{\circ} \mathrm{S}$ sufficiently to allow a southern temperate fauna to survive in Antarctica. This scenario would allow more Subantarctic endemic species (Group 3) to survive at the Antarctic Peninsula but they would lose their original suitable habitat. No habitat colder than $0{ }^{\circ} \mathrm{C}$ would exist under this most extreme hypothetical case, except for under floating ice shelves, meaning that only species from Groups 4 to 7 would be capable of inhabiting most of the Antarctic shelf, potentially causing the extinction of many Antarctic endemic species (Groups 9 and 10) and restricting the majority (Group 8) to the Weddell Sea and part of the Ross Sea.

Under the RCP8.5 scenario, warming is projected to continue beyond the year 2100 and therefore to set the 2100 projections into a longer-term context we examined a more limited ensemble with RCP8.5 projections available up to 2200 (Supplementary Table 1). The mean of this more limited ensemble revealed a general pattern of further warming, a consequence of which is that the majority of the subzero waters are lost along with most of the suitable habitat for endemic Antarctic species (Supplementary Figs. 2 and 3). The additional warming brings the 2200 ensemble mean warming to levels similar to, but still less severe than, the previously discussed 2099 ensemble local extreme in projected warming for each pixel (Fig 6).

\section{Discussion:}

Marine species have four potential responses to projected warming:

- Going deeper: species capable of shifting their bathymetric range into cooler, deeper water may be able to maintain their present-day latitudinal distribution ${ }^{1,3,13}$. 
- Poleward migration: for shelf-restricted organisms this range shift is dependent on availability of suitable habitat at higher latitudes ${ }^{1,3,13}$.

- Adaptation: species may be able to adapt their behaviour or physiology to mitigate against rising temperatures ${ }^{3,14,15}$.

- Extinction: Species unable to find suitable habitat elsewhere, and unable to complete their lifecycle or are outcompeted at higher temperatures are likely to become locally or globally extinct $^{3,8,16}$.

For Antarctic shelf species deeper water and southerly migration are not an option as they already inhabit the coldest water on Earth in its most southerly marine locations, both of which are found in the Ross and Weddell Sea shelves. Previous global analysis of thermal tolerance and latitude in ectotherms suggested that marine organisms from south of $60^{\circ} \mathrm{S}$ had the narrowest tolerance range of anywhere on the planet ${ }^{2}$. Our results suggest that reduction in range area along with probable localised extinctions will affect around $79 \%$ of species endemic to south of the Polar Front.

Antarctic benthos is generally considered to be poorly suited to warmer temperatures ${ }^{15}$, with small experimental rises of 2 or $3{ }^{\circ} \mathrm{C}$ above normal drastically reducing their ability to carry out critical functions ${ }^{17}$. Two to three degrees is a large change in the model mean temperature south of the Polar Front, and most regions are predicted to experience smaller changes (average projected increase of 0.4 ${ }^{\circ} \mathrm{C}$, with a maximum of $2.15^{\circ} \mathrm{C}$ ) (Fig. 1). However, limited evidence from environments which are extreme and highly seasonal, even by polar marine standards, the Antarctic intertidal, suggest that some endemic species (e.g. Laternula elliptica, member of Group 6) are capable of surviving far warmer temperatures $\left(7.5^{\circ} \mathrm{C}\right)$ than would be expected from laboratory experiments ${ }^{18}$. Under experimental conditions, L. elliptica has been shown to suffer complete loss of function at $5{ }^{\circ} \mathrm{C}$, although there is some anecdotal evidence that individuals can survive for over a month at $3{ }^{\circ} \mathrm{C}^{19,20}$. Quilty et al. ${ }^{21}$ found fossils of present day endemic Antarctic species, including L. elliptica, and South American molluscs living side by side in East Antarctica in the Pliocene at temperatures of between 4 and $7.5^{\circ} \mathrm{C}$. Based on this evidence it may be the case that at least some of these cold water species are capable of tolerating the projected rise in temperatures with limited effect on their distribution. 
The potential for marine invasive species in Antarctic waters, similar to those already observed for terrestrial habitats ${ }^{22}$, have been the subject of much speculation ${ }^{7,23}$. The existing (and future) meridional temperature gradients across the SAF and PF are larger than the projected warming change either north or south of these fronts, meaning it will still be colder on the southern side of the front in the future than it is on the present northern side. Therefore these fronts will continue to be significant barriers to potential invasive species, however, very few laboratory-based physiological studies of the lower thermal tolerances of these species exist ${ }^{2}$. One potential source of invasive species into Antarctica that has only recently been recognised is the introduction of cold tolerant Northern Hemisphere and Arctic species via ships and ballast water ${ }^{24}$.

Our findings show that under strongly warming climate change scenarios species in Antarctic waters are likely to experience a range shift, with some geographic areas losing species and others opening up to a range of previously excluded Antarctic species (Fig. 5). How these changes to communities will affect ecosystem structure and function is unknown ${ }^{16}$, although it is likely to lead to some species benefiting and many others being disadvantaged. The timings of seasonal dependant reproduction and feeding, predator-prey relationships, assemblage structure, habitat complexity, susceptibility to parasites and disease and interspecific competition for resources are all likely to change in a warming environment ${ }^{25}$ and may have unforeseeable additional effects on species' distribution and abundances.

Projected changes in species richness do not, however, directly equate to changes in biomass or ecosystem function. The addition of new consumers or ecosystem engineers to a community has been shown to have a dramatic effect on communities, even without a change in temperature ${ }^{26}$. Species such as durophagous king crabs have been a major recent topic of discussion regarding the present and future of the Antarctic benthos ${ }^{27,28}$. King crabs found at South Georgia (south of the PF) at the present day include species from Group 5 (Paralomis spinosissima) and Group 7 (P. anamerae and P. formosa) which are capable of living at temperatures currently found on the West Antarctic Peninsula shelf but are not found living there today ${ }^{27}$. However, the present day distribution of native Antarctic king crabs (south of $60{ }^{\circ} \mathrm{S}$ ) is deeper than $1000 \mathrm{~m}^{27}$ (beyond the bathymetric scope of this study) and those 
shallower dwelling species found north of the PF (e.g. Lithodes santolla from Group 2) will not be able to tolerate temperatures in Antarctic waters given the projected levels of warming.

Warming ocean temperature is not the only physical factor associated with projected environmental change in the Southern Ocean ${ }^{29,30}$, with shelf regions likely to be most affected by multiple changes ${ }^{30}$. While we show that temperature changes alone are unlikely to drive significant levels of extinctions, associated changes such as ocean acidification and changes to sea-ice and convection patterns have the potential to affect the entire ecosystem, altering food and light availability and causing physiological stress $^{16,29,30}$ and may have a synergistic negative effects on species already facing habitat reduction due to warming. With fishing in the region likely to be of increasing importance to global food supplies ${ }^{30,31}$, this may represent a further stress upon the ecosystem, further affecting those species facing a reduction in suitable habitat.

Our findings highlight the organisms and geographic regions most likely to respond significantly (negatively or positively) to projected seafloor warming in and around the Southern Ocean. Evidence from 963 benthic species, even under the strongly warming RCP8.5 climate projections, suggests that, when considered in isolation, the effect of projected warming on Antarctic shelf seafloor life results in substantial redistribution rather than wholesale extinction or invasion. The cold adapted endemic species native to the region south of the Polar Front face a reduction in suitable habitat and may require additional management and conservation measures in future to minimise the additional effects of other changes and human impacts.

\section{Corresponding author:}

Correspondence and requests for materials should be addressed to Huw J. Griffiths

\section{Acknowledgements:}

The authors would like to thank Dr Alix Post, Dr Cath Waller, Dr Katrin Linse, Dr Sally Thorpe, Prof John Turner and Prof David Vaughan for their useful advice. We thank all the contributors of data and expert knowledge to the SCAR Biogeographic Atlas of the Southern Ocean. We thank Dr Anton Van de Putte for helping to prepare the species occurrence data. We acknowledge the World Climate 
Research Programme's Working Group on Coupled Modelling, which is responsible for CMIP, and we thank the climate modelling groups for producing and making available their model output. This paper contributes to the SCAR 'State of the Antarctic Ecosystem' (AntEco) and 'Antarctic Climate Change in the 21st Century' (AntClim21) programmes. Andrew Meijers was supported by NERC grant NE/N018095/1 (Ocean Regulation of Climate by Heat and Carbon Sequestration and Transports;

\section{ORCHESTRA).}

\section{Author Contributions}

HJG analysed the data; AJSM prepared the oceanographic data; All authors wrote the manuscript.

\section{Competing financial interests}

The authors declare no competing financial interests.

\section{References}

1 Perry, A. L., Low, P. J., Ellis, J. R. \& Reynolds, J. D. Climate Change and Distribution Shifts in Marine Fishes. Science 308, 1912-1915 (2005).

2 Sunday, J. M., Bates, A. E. \& Dulvy, N. K. Global analysis of thermal tolerance and latitude in ectotherms. Proceedings of the Royal Society of London B: Biological Sciences 278, 18231830 (2011).

3 Poloczanska, E. S. et al. Responses of marine organisms to climate change across oceans. Frontiers in Marine Science 3, 62 (2016).

4 Barnes, D. K., Griffiths, H. J. \& Kaiser, S. Geographic range shift responses to climate change by Antarctic benthos: where we should look. Marine Ecology Progress Series 393, 13-26 (2009).

5 Wassmann, P., Duarte, C. M., Agusti, S. \& Sejr, M. K. Footprints of climate change in the Arctic marine ecosystem. Global change biology 17, 1235-1249 (2011).

6 Griffiths, H. J., Barnes, D. K. \& Linse, K. Towards a generalized biogeography of the Southern Ocean benthos. Journal of Biogeography 36, 162-177 (2009).

7 Clarke, A., Barnes, D. K. \& Hodgson, D. A. How isolated is Antarctica? Trends in Ecology \& Evolution 20, 1-3 (2005).

8 Cheung, W. W. et al. Projecting global marine biodiversity impacts under climate change scenarios. Fish and Fisheries 10, 235-251 (2009).

9 Beaugrand, G., Edwards, M., Raybaud, V., Goberville, E. \& Kirby, R. R. Future vulnerability of marine biodiversity compared with contemporary and past changes. Nature Climate Change 5, 695-701 (2015).

10 Molinos, J. G. et al. Climate velocity and the future global redistribution of marine biodiversity. Nature Climate Change (2015).

11 Griffiths, H. J. Antarctic marine biodiversity-what do we know about the distribution of life in the Southern Ocean? PloS one 5, e11683 (2010). 
12 Van Vuuren, D. P. et al. The representative concentration pathways: an overview. Climatic change 109, 5 (2011).

13 Dulvy, N. K. et al. Climate change and deepening of the North Sea fish assemblage: a biotic indicator of warming seas. Journal of Applied Ecology 45, 1029-1039 (2008).

14 Hughes, T. P. et al. Climate change, human impacts, and the resilience of coral reefs. science 301, 929-933 (2003).

15 Somero, G. The physiology of climate change: how potentials for acclimatization and genetic adaptation will determine 'winners' and 'losers'. Journal of Experimental Biology 213, 912920 (2010).

16 Hoegh-Guldberg, O. \& Bruno, J. F. The impact of climate change on the world's marine ecosystems. Science 328, 1523-1528 (2010).

17 Barnes, D. K. \& Peck, L. S. Vulnerability of Antarctic shelf biodiversity to predicted regional warming. Climate Research 37, 149-163 (2008).

18 Waller, C. L., Overall, A., Fitzcharles, E. M. \& Griffiths, H. First report of Laternula elliptica in the Antarctic intertidal zone. Polar Biology 40, 227-230 (2017).

19 Peck, L. S., Clark, M. S., Morley, S. A., Massey, A. \& Rossetti, H. Animal temperature limits and ecological relevance: effects of size, activity and rates of change. Functional Ecology 23, 248-256 (2009).

20 Peck, L. S., Webb, K. E. \& Bailey, D. M. Extreme sensitivity of biological function to temperature in Antarctic marine species. Functional Ecology 18, 625-630 (2004).

21 Quilty, P. G., Darragh, T. A., Gallagher, S. J. \& Harding, L. A. Pliocene Mollusca (Bivalvia, Gastropoda) from the Sørsdal Formation, Marine Plain, Vestfold Hills, East Antarctica: taxonomy and implications for Antarctic Pliocene palaeoenvironments. Alcheringa: An Australasian Journal of Palaeontology 40, 556-582 (2016).

22 Chown, S. L. et al. Continent-wide risk assessment for the establishment of nonindigenous species in Antarctica. Proceedings of the National Academy of Sciences 109, 4938-4943 (2012).

23 Chown, S. L. et al. The changing form of Antarctic biodiversity. Nature 522, 431-438 (2015).

24 Byrne, M., Gall, M., Wolfe, K. \& Agüera, A. From pole to pole: the potential for the Arctic seastar Asterias amurensis to invade a warming Southern Ocean. Global change biology 22, 3874-3887 (2016).

25 Parmesan, C. Ecological and evolutionary responses to recent climate change. Annu. Rev. Ecol. Evol. Syst. 37, 637-669 (2006).

26 Britayev, T., Rzhavsky, A., Pavlova, L. \& Dvoretskij, A. Studies on impact of the alien Red King Crab (Paralithodes camtschaticus) on the shallow water benthic communities of the Barents Sea. Journal of Applied Ichthyology 26, 66-73 (2010).

27 Griffiths, H. J., Whittle, R. J., Roberts, S. J., Belchier, M. \& Linse, K. Antarctic crabs: invasion or endurance? PLoS One 8, e66981 (2013).

28 Aronson, R. B. et al. No barrier to emergence of bathyal king crabs on the Antarctic shelf. Proceedings of the National Academy of Sciences 112, 12997-13002 (2015).

29 Gutt, J. et al. The Southern Ocean ecosystem under multiple climate change stresses-an integrated circumpolar assessment. Global change biology 21, 1434-1453 (2015).

30 Constable, A. J. et al. Climate change and Southern Ocean ecosystems I: how changes in physical habitats directly affect marine biota. Global Change Biology 20, 3004-3025 (2014).

31 Cheung, W. W. et al. Large-scale redistribution of maximum fisheries catch potential in the global ocean under climate change. Global Change Biology 16, 24-35 (2010).

Methods:

\section{Ocean Temperature}


Models from the CMIP5 coupled climate ensemble were selected from all available output in the UK Centre for Environmental Data Analysis (CEDA) CMIP5 database. Models were selected on the basis of having monthly averaged ocean potential temperature (thetao) output for both the historical (HIST) scenario for the years 1975-2005 and the strong climate Representative Concentration Pathway 8.5 for years 2070-2099 $(\mathrm{RCP} 8.5)^{32}$. RCP8.5 refers to the approximate change in radiative forcing in $\mathrm{Wm}^{-2}$ by the year 2100 and is sometimes referred to as a 'business as usual scenario ${ }^{12}$. It includes a full range of anthropogenic forcing factors (greenhouse gases, aerosols, chemically active gases and land use) along with a repeating 11 year solar cycle ${ }^{33}$ and drives significant changes in Southern Ocean temperature, circulation, salinity, winds and sea ice extent by $2100^{34}$. These changes are more extreme in RCP8.5, but tend to be qualitatively similar in the Southern Ocean to milder climate forcing scenarios such as RCP4. $55^{35,36}$. It is worth noting that while the future projections of the Southern Ocean have significant dynamical disagreements across the CMIP5 ensemble, warming on the continental shelves and upper ocean is a robust feature ${ }^{34,37}$.

Each model was interpolated onto a regular 1x1 degree latitude and longitude grid and the austral summer months (JFM) temporally averaged over the respective HIST and RCP8.5 thirty year periods. Bottom properties were then extracted based on the deepest non-empty thetao value at each lat-lon gridpoint. Note that this represents the temperature over the entire bottom cell, which in deeper model layers may extend for $250 \mathrm{~m}$ or more vertically, rather than the temperature at the exact sea bed. For layers shallower than 1,000 m vertical cell extents are on the order of 10-100 m depending on the model.

The model ensemble was further reduced by rejecting the CNRM-CM5 models due to significantly outlying (warm) bottom temperature properties and the HadGEM2-AO due to issues identifying the bottom cell. This left us with 19 models (Supplementary Table 1) with both HIST and RCP8.5 averaged austral summer time bottom temperatures for the given years. Mean ensemble temperatures and standard deviations for each ensemble were then calculated elementwise at each latitude and longitude cell. To test if the elementwise model changes between the two scenarios is statistically significant we applied a dependent t-test for paired samples on the differences. Excluding some gridpoints abutting the coastline where model topographies varied due to differing resolutions, and regions of the abyssal 
ocean where temperature changes were small, most of the model domain shows significant bottom temperature changes between the HIST and RCP8.5 scenarios at the 95\% confidence level, agreeing with similar studies of Southern Ocean properties ${ }^{37}$.

Austral winter (JJA) mean temperatures were calculated and it was found that they produced similar patterns of change between the HIST and RCP8.5 scenarios, but tended towards slightly weaker average temperature changes. We therefore proceeded to use the summer values as example of the peak temperature changes experienced in a seasonal cycle. To investigate the extremes of the future ensemble we also constructed a local ensemble maximum benthic temperature change map, where the model with the most extreme RCP8.5 temperature change at each grid point was used, rather than the ensemble average. This represents the most extreme change predicted at each grid point, and is not consistent with any one model output. No one model completely dominated this output, meaning we can be relatively happy that it isn't driven entirely by one spurious ensemble member. This method is also more susceptible to biases induced by intra-model variability in the averaging periods. At regional scales interannual temperature variability within a single model often overwhelms the climate signal, so this analysis should be viewed only as a hypothetical exploration of extreme upper bounds of the ensemble, rather than a reasonable prediction of potential change.

\section{Biogeographic Records}

The biological data were extracted from the expert validated database for Part 5. Biogeographic Patterns of Benthos of the Scientific Committee on Antarctic Research Biogeographic Atlas of the Southern Ocean ${ }^{38}$ with additional records for taxa with limited data from north of $50{ }^{\circ} \mathrm{S}$ (Sipuncula, Annelida, Mysida and Crinoidea) extracted from the Ocean Biogeographic Information System (http://iobis.org/). All benthic species with 20 or more records, at depths shallower than 1,000 m and from south of $40^{\circ} \mathrm{S}$ were selected. All species names were validated using the World Register of Marine Species (http://www.marinespecies.org/). The 963 selected species included 10 phyla (Annelida, Arthropoda, Bryozoa, Chordata, Cnidaria, Echinodermata, Mollusca, Nematoda, Porifera and 
Sipuncula) representing 21 classes. A total of 57,827 benthic occurrence records were used. Of these species, 390 were only found south of the Polar Font, 426 had ranges which crossed the Polar Front and 147 were only known from north of the Polar Front.

Biological record locations were overlaid onto the modelled seafloor temperature data and present day temperature values were assigned to each record. As the georeferenced biological data were limited to occurrence and had no abundance data, the thermal range of each species was defined uniformly as any temperature between the minimum and maximum temperatures of its present-day distribution. Species were clustered into groups of species with similar thermal limits and temperature range size using Bray Curtis Similarity in PRIMER $6^{39}$. All analyses of potential distributions under projected temperatures were carried out using RCP8.5 mean ensemble seafloor temperatures for 2099. Present-day and projected future species potential range areas are based upon the area of seafloor habitat anywhere in the study region at temperatures suitable for that species, irrespective of whether that species had been found in that geographical area. Species turnover analyses assumed that all species are equally capable of migrating to any part of the study region with a suitable temperature, irrespective of life history traits. Depth ranges of species were not included in the analyses, with all pixels at depths shallower than 1,000 m treated equally.

\section{Data availability}

The authors declare that the data supporting the findings of this study are available from $\underline{\text { Biodiversity.aq, the Ocean Biogeographic Information System and the UK Centre for Environmental }}$ Data Analysis.

\section{Methods References}

32 Taylor, K. E., Stouffer, R. J. \& Meehl, G. A. An overview of CMIP5 and the experiment design. Bulletin of the American Meteorological Society 93, 485-498 (2012).

33 Meinshausen, M. et al. The RCP greenhouse gas concentrations and their extensions from 1765 to 2300. Climatic change 109, 213 (2011). 
34 Meijers, A. The Southern Ocean in the coupled model intercomparison project phase 5. Philosophical Transactions of the Royal Society of London A: Mathematical, Physical and Engineering Sciences 372, 20130296 (2014).

35 Meijers, A. et al. Representation of the Antarctic Circumpolar Current in the CMIP5 climate models and future changes under warming scenarios. Journal of Geophysical Research: Oceans 117 (2012).

36 Bracegirdle, T. J. et al. Assessment of surface winds over the Atlantic, Indian, and Pacific Ocean sectors of the Southern Ocean in CMIP5 models: historical bias, forcing response, and state dependence. Journal of Geophysical Research: Atmospheres 118, 547-562 (2013).

37 Sallée, J. B. et al. Assessment of Southern Ocean water mass circulation and characteristics in CMIP5 models: Historical bias and forcing response. Journal of Geophysical Research: Oceans 118, 1830-1844 (2013).

38 De Broyer, C. et al. in Biogeographic Atlas of the Southern Ocean (eds Claude De Broyer et al.) Ch. 5, 65-252 (Scientific Committee on Antarctic Research, 2014).

39 Clarke, K. \& Gorley, R. PRIMER v6: User Manual/Tutorial. (PRIMER-E, 2006).

\section{Figures captions:}

Figure 1. Temperature anomaly $\left({ }^{\circ} \mathrm{C}\right)$ in 2005 to 2099 using RCP8.5 mean ensemble shelf benthic temperatures $(<1,000 \mathrm{~m})$. Black dots indicate a significant difference exists at the $95 \%$ level between the 2005 and 2099 ensembles. Dashed line is $60^{\circ}$ S, grey area is south of the Polar Front (as defined by Moore et al., 1999). SG = South Georgia, SO = South Orkney Islands, AP = Antarctic Peninsula, $\mathrm{KP}=$ Kerguelen Plateau.

Figure 2. Temperature ranges of benthic invertebrates from south of $40^{\circ} \mathrm{S}$ and projected change in seafloor temperatures south of the Polar Front.

a) Temperature ranges of seafloor invertebrates grouped by $>80 \%$ similarity in their thermal distribution patterns. Coloured bars $=$ the mean temperature range experienced by a group, numbers are the number of species represented by each group. Black bars = the maximum and minimum temperature range experienced by any of the species within a group (more detail given in Supplementary Table 2). The 2005 (blue) and 2099 (red) maximum temperatures for the shelf area ( $<1,000 \mathrm{~m}$ deep) south of $60^{\circ} \mathrm{S}$ (solid line) and that south of the Polar Front (dashed line). Area $=$ area of seabed south of $60^{\circ} \mathrm{S}$ experiencing a given temperature.

b) Area covered by present and projected future seafloor temperatures (RCP8.5 ensemble mean) south of $60^{\circ} \mathrm{S}$. 
c) The percentage of species within each group projected to gain or lose potential habitat area. Red and blue bars indicate the percentage of species experiencing an increase (red) and decrease (blue) in their suitable temperature habitat.

Figure 3. Mean ensemble seafloor temperatures $\left({ }^{\circ} \mathrm{C}\right)$ averaged over the historical scenario (19762005) and over 2070-2099 under RCP8.5 projections. Dashed line is $60^{\circ} \mathrm{S}$, grey area is south of the Polar Front (as defined by Moore et al., 1999).

Figure 4. The number of species that are predicted to experience a change (increase or decrease) in potentially available area of seafloor at suitable temperatures by 2099 under the RCP8.5 scenario.

Figure 5. Species change/turnover (gain + loss) by 2099 as a percentage of the original number of species potentially inhabiting each a pixel (based upon suitable present day temperature ranges, using RCP8.5 mean ensemble projections). Dashed line is $60^{\circ} \mathrm{S}$, grey area is south of the Polar Front (as defined by Moore et al., 1999).

Figure 6. a) Maximum projected values of seafloor temperature $\left({ }^{\circ} \mathrm{C}\right)$ per gridcell within the RCP8.5 ensemble and b) the anomaly between the mean model and the maximum individual model value per grid cells $\left({ }^{\circ} \mathrm{C}\right.$ ). Dashed line is $60^{\circ} \mathrm{S}$, grey area is south of the Polar Front (as defined by Moore et al., 1999). 


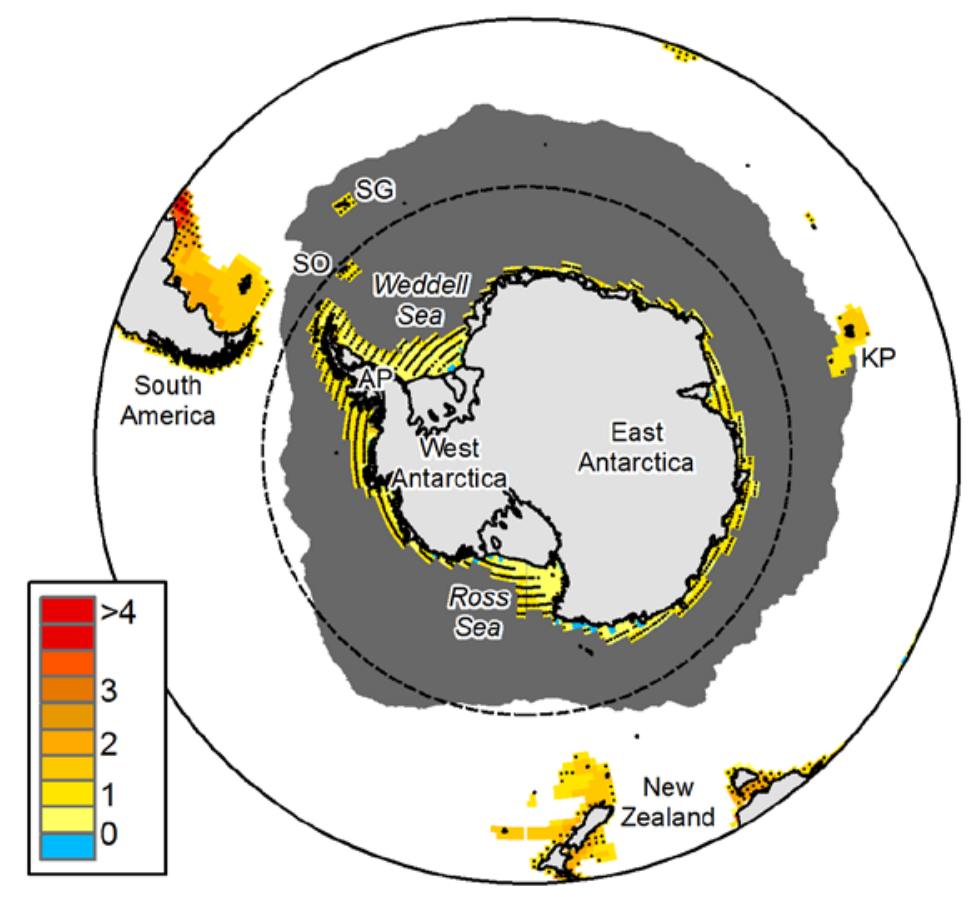

Figure 1. Temperature anomaly $\left({ }^{\circ} \mathrm{C}\right)$ in 2005 to 2099 using RCP8.5 mean ensemble shelf benthic temperatures $(<1,000 \mathrm{~m})$. Black dots indicate a significant difference exists at the $95 \%$ level between the 2005 and 2099 ensembles. Dashed line is $60^{\circ} \mathrm{S}$, grey area is south of the Polar Front (as defined by Moore et al., 1999). SG = South Georgia, SO = South Orkney Islands, AP = Antarctic Peninsula, $\mathrm{KP}=$ Kerguelen Plateau . 


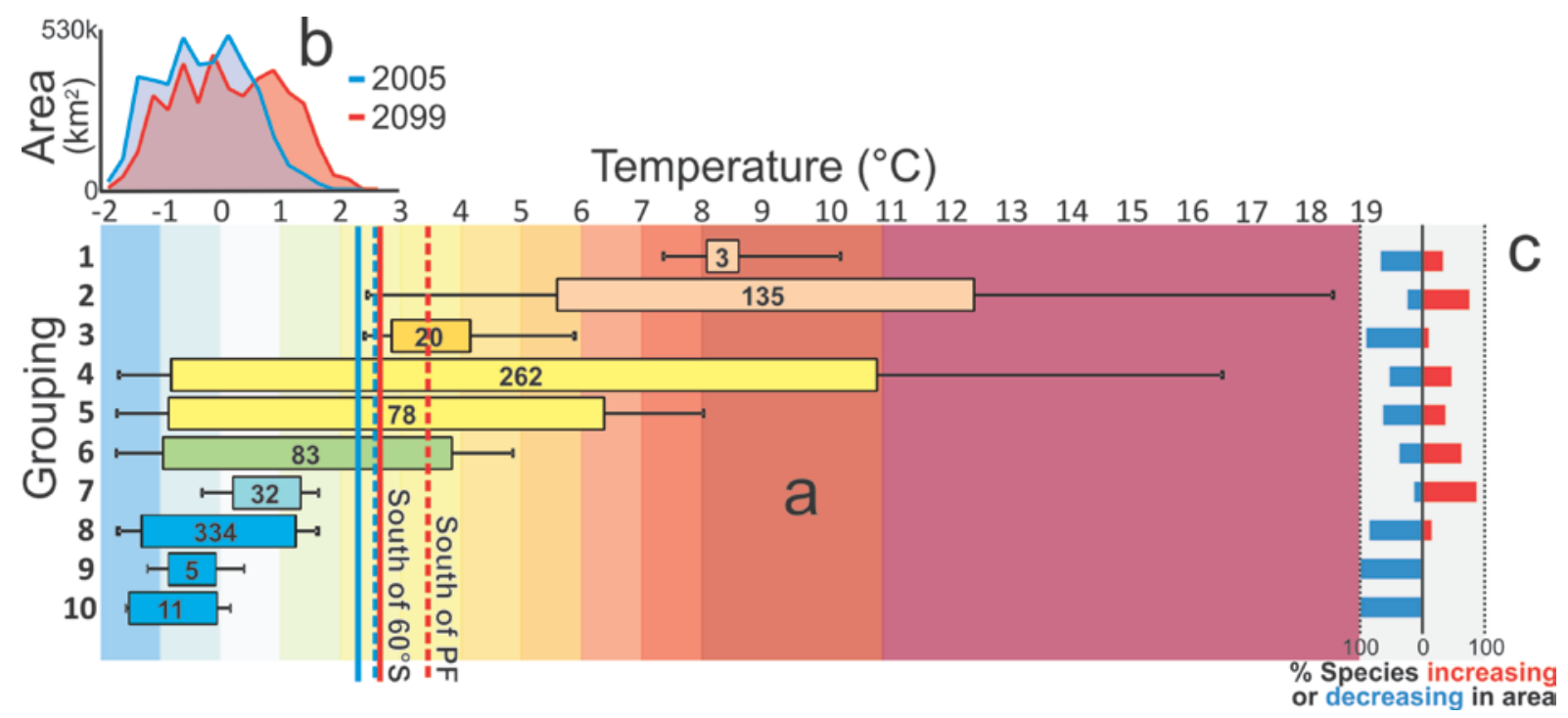

Figure 2. Temperature ranges of benthic invertebrates from south of $40^{\circ} \mathrm{S}$ and projected change in seafloor temperatures south of the Polar Front.

a) Temperature ranges of seafloor invertebrates grouped by $>80 \%$ similarity in their thermal distribution patterns. Coloured bars $=$ the mean temperature range experienced by a group, numbers are the number of species represented by each group. Black bars = the maximum and minimum temperature range experienced by any of the species within a group (more detail given in Supplementary Table 2). The 2005 (blue) and 2099 (red) maximum temperatures for the shelf area ( $<1,000 \mathrm{~m}$ deep) south of $60^{\circ} \mathrm{S}$ (solid line) and that south of the Polar Front (dashed line). Area $=$ area of seabed south of $60^{\circ} \mathrm{S}$ experiencing a given temperature.

b) Area covered by present and projected future seafloor temperatures (RCP8.5 ensemble mean) south of $60^{\circ} \mathrm{S}$.

c) The percentage of species within each group projected to gain or lose potential habitat area. Red and blue bars indicate the percentage of species experiencing an increase (red) and decrease (blue) in their suitable temperature habitat. 


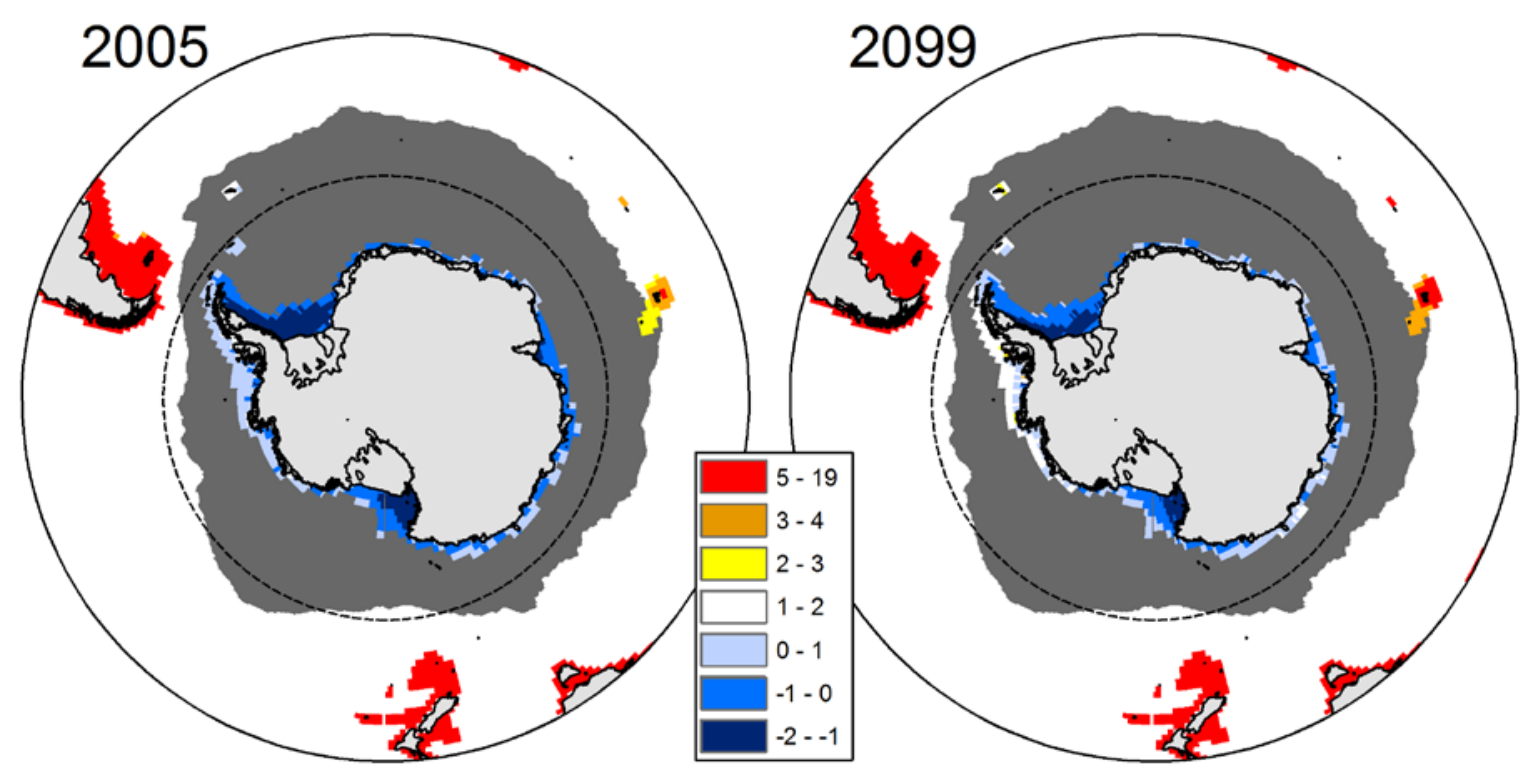

Figure 3. Mean ensemble seafloor temperatures $\left({ }^{\circ} \mathrm{C}\right)$ averaged over the historical scenario (19762005) and over $2070-2099$ under RCP8.5 projections. Dashed line is $60^{\circ} \mathrm{S}$, grey area is south of the Polar Front (as defined by Moore et al., 1999).

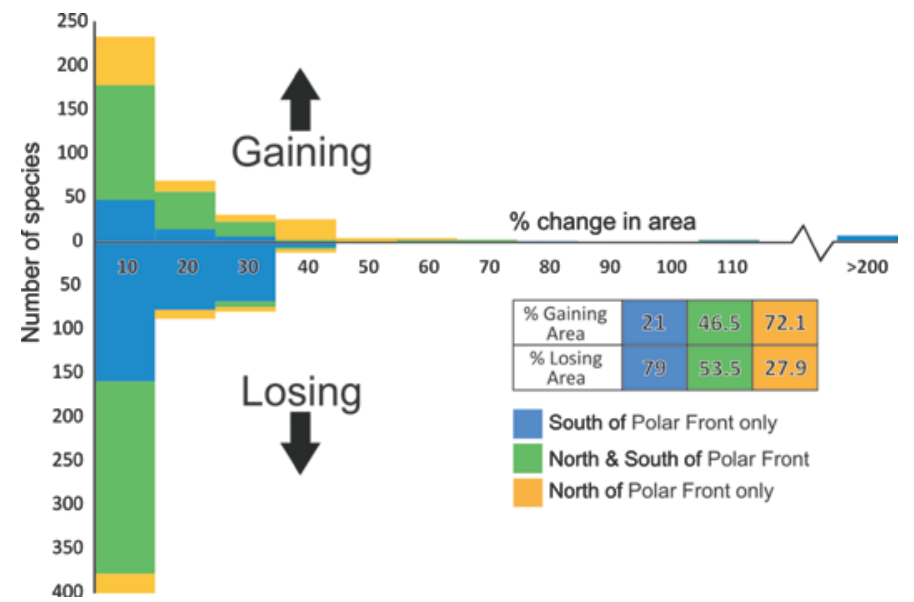

Figure 4. The number of species that are predicted to experience a change (increase or decrease) in potentially available area of seafloor at suitable temperatures by 2099 under the RCP8.5 scenario. 


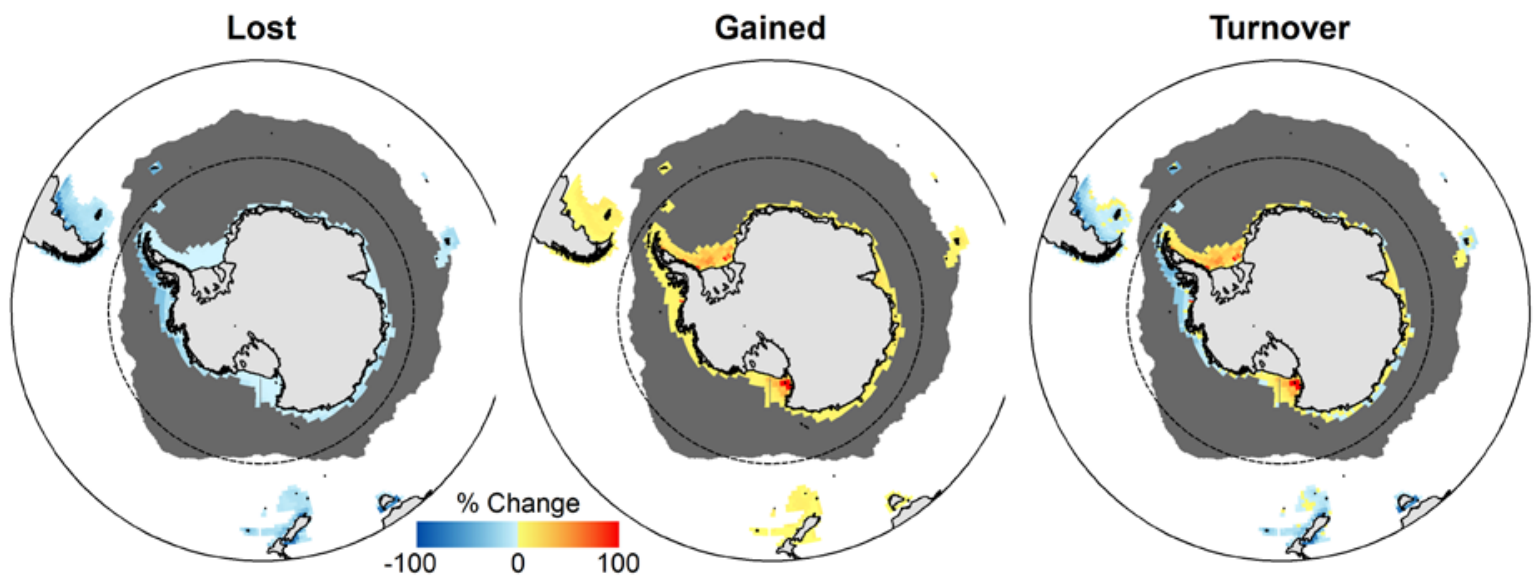

Figure 5. Species change/turnover (gain + loss) by 2099 as a percentage of the original number of species potentially inhabiting each a pixel (based upon suitable present day temperature ranges, using RCP8.5 mean ensemble projections). Dashed line is $60^{\circ} \mathrm{S}$, grey area is south of the Polar Front (as defined by Moore et al., 1999).
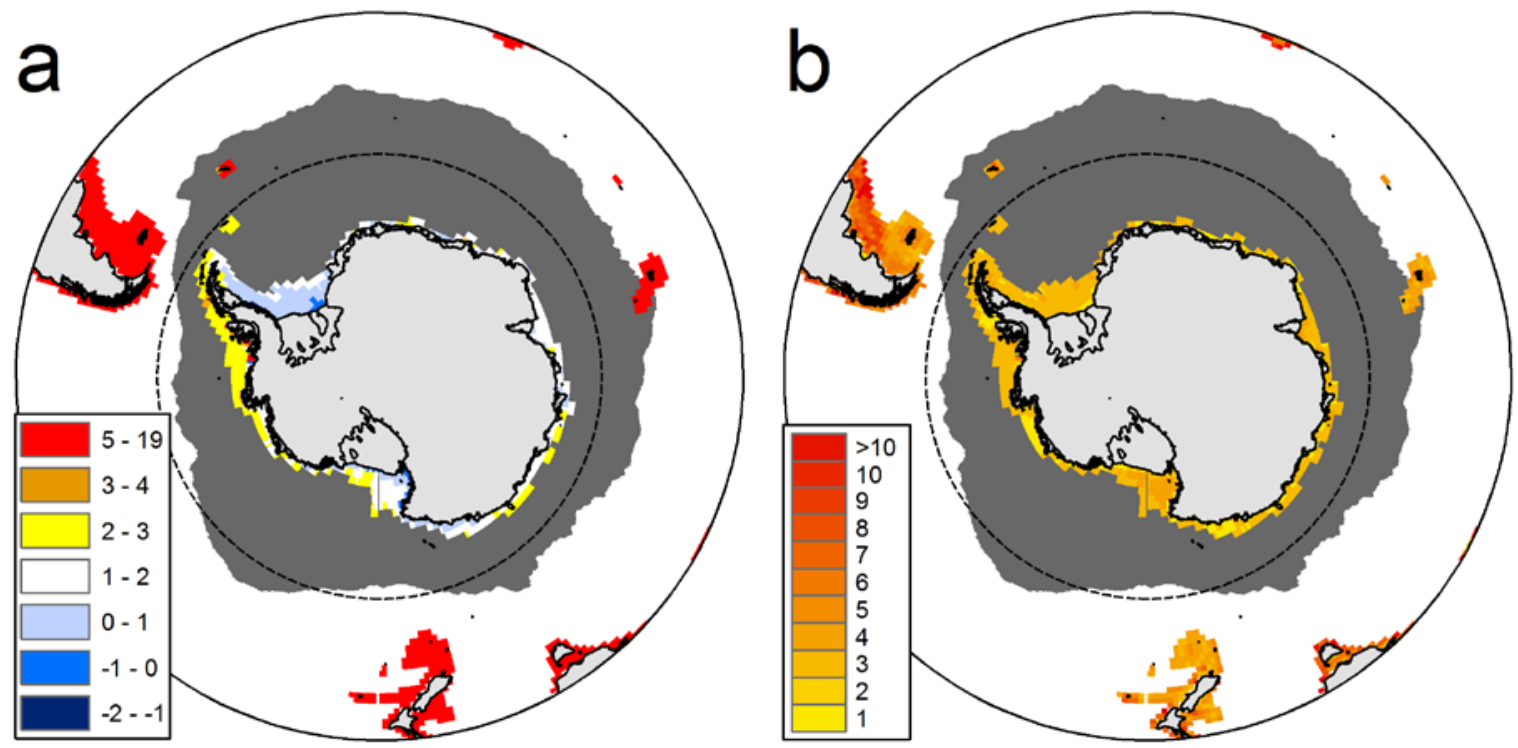

Figure 6. a) Maximum projected values of seafloor temperature $(\mathrm{OC})$ per gridcell within the RCP8.5 ensemble and $b$ ) the anomaly between the mean model and the maximum individual model value per grid cells (oC). Dashed line is $60^{\circ} \mathrm{S}$, grey area is south of the Polar Front (as defined by Moore et al., 1999). 


\section{More losers than winners in a century of future Southern Ocean seafloor warming}

Huw J Griffiths*, Andrew JS Meijers, Thomas J Bracegirdle

British Antarctic Survey, Cambridge, UK hjg@bas.ac.uk

\section{Supplementary Information}

Supplementary Table 1. Models represented in the ensemble for present day and 2099 (RCP8.5). * = Models used for 2200 ensemble (RCP8.5).

\begin{tabular}{|c|c|c|}
\hline Modeling Center & Model & Institution \\
\hline \multirow{2}{*}{ BCC } & BCC-CSM1.1* & \multirow{2}{*}{$\begin{array}{l}\text { Beijing Climate Center, China Meteorological } \\
\text { Administration }\end{array}$} \\
\hline & BCC-CSM1.1(m) & \\
\hline CCCma & CanESM2 & Canadian Centre for Climate Modelling and Analysis \\
\hline CSIRO-QCCCE & CSIRO-Mk3.6.0* & $\begin{array}{l}\text { Commonwealth Scientific and Industrial Research } \\
\text { Organisation in collaboration with the Queensland } \\
\text { Climate Change Centre of Excellence }\end{array}$ \\
\hline INM & INM-CM4 & Institute for Numerical Mathematics \\
\hline \multirow{3}{*}{ IPSL } & IPSL-CM5A-LR* & \multirow{3}{*}{ Institut Pierre-Simon Laplace } \\
\hline & IPSL-CM5A-MR & \\
\hline & IPSL-CM5B-LR & \\
\hline \multirow{2}{*}{$\begin{array}{l}\text { MOHC (additional } \\
\text { realizations by INPE) }\end{array}$} & HadGEM2-CC & \multirow{2}{*}{$\begin{array}{l}\text { Met Office Hadley Centre (additional HadGEM2-ES } \\
\text { realizations contributed by Instituto Nacional de } \\
\text { Pesquisas Espaciais) }\end{array}$} \\
\hline & HadGEM2-ES* & \\
\hline \multirow{4}{*}{ NASA GISS } & GISS-E2-H* & \multirow{4}{*}{ NASA Goddard Institute for Space Studies } \\
\hline & GISS-E2-H-CC & \\
\hline & GISS-E2-R* & \\
\hline & GISS-E2-R-CC & \\
\hline NCAR & CESM1-CAM5 & National Center for Atmospheric Research \\
\hline \multirow{2}{*}{ NCC } & NorESM1-M & \multirow{2}{*}{ Norwegian Climate Centre } \\
\hline & NorESM1-ME & \\
\hline \multirow{2}{*}{ NOAA GFDL } & GFDL-ESM2G & \multirow{2}{*}{ Geophysical Fluid Dynamics Laboratory } \\
\hline & GFDL-ESM2M & \\
\hline
\end{tabular}


Supplementary Table 2. Groupings of seafloor invertebrates from south of $40^{\circ} \mathrm{S}$, grouped by $>80 \%$ similarity in their thermal distribution patterns.

\begin{tabular}{|c|c|c|c|l|}
\hline Group & $\begin{array}{c}\text { Minimum } \\
\text { Temperature }\end{array}$ & $\begin{array}{c}\text { Maximum } \\
\text { Temperature }\end{array}$ & $\begin{array}{c}\text { No. of } \\
\text { Species }\end{array}$ & \multicolumn{1}{|c|}{ Example Species } \\
\hline 1 & 7.4 & 10.3 & 3 & Thaumatometra alternata, Tawera sphaericula \\
\hline 2 & 2.4 & 18.5 & 135 & $\begin{array}{l}\text { Lithodes santolla, Mytilus edulis, Henricia } \\
\text { compacta }\end{array}$ \\
\hline 3 & 2.4 & 5.9 & 20 & $\begin{array}{l}\text { Lithodes murrayi, Sterechinus diadema, Admete } \\
\text { specularis }\end{array}$ \\
\hline 4 & -1.8 & 16.7 & 262 & $\begin{array}{l}\text { Bathybiaster loripes, Chorismus antarcticus, } \\
\text { Colossendeis megalonyx }\end{array}$ \\
\hline 5 & -1.8 & 8.0 & 78 & $\begin{array}{l}\text { Ammothea longispina, Rossella racovitzae, } \\
\text { Sterechinus neumayeri }\end{array}$ \\
\hline 6 & -1.8 & 4.8 & 83 & $\begin{array}{l}\text { Munna antarctica, Laternula elliptica, Rossella } \\
\text { antarctica }\end{array}$ \\
\hline 7 & -0.3 & 1.6 & 32 & $\begin{array}{l}\text { Paralomis formosa, Caryophyllia eltaninae, } \\
\text { Chlanidota paucispiralis }\end{array}$ \\
\hline 8 & -1.8 & 1.6 & 334 & $\begin{array}{l}\text { Adamussium colbecki, Glyptonotus antarcticus, } \\
\text { Cellarinella nutti }\end{array}$ \\
\hline 9 & -1.2 & 0.4 & 5 & Epimeria rubrieques, Falsimargarita thielei \\
\hline 10 & -1.6 & 0.1 & 11 & Abatus (Pseudabatus) nimrodi, Carditella mawsoni \\
\hline
\end{tabular}



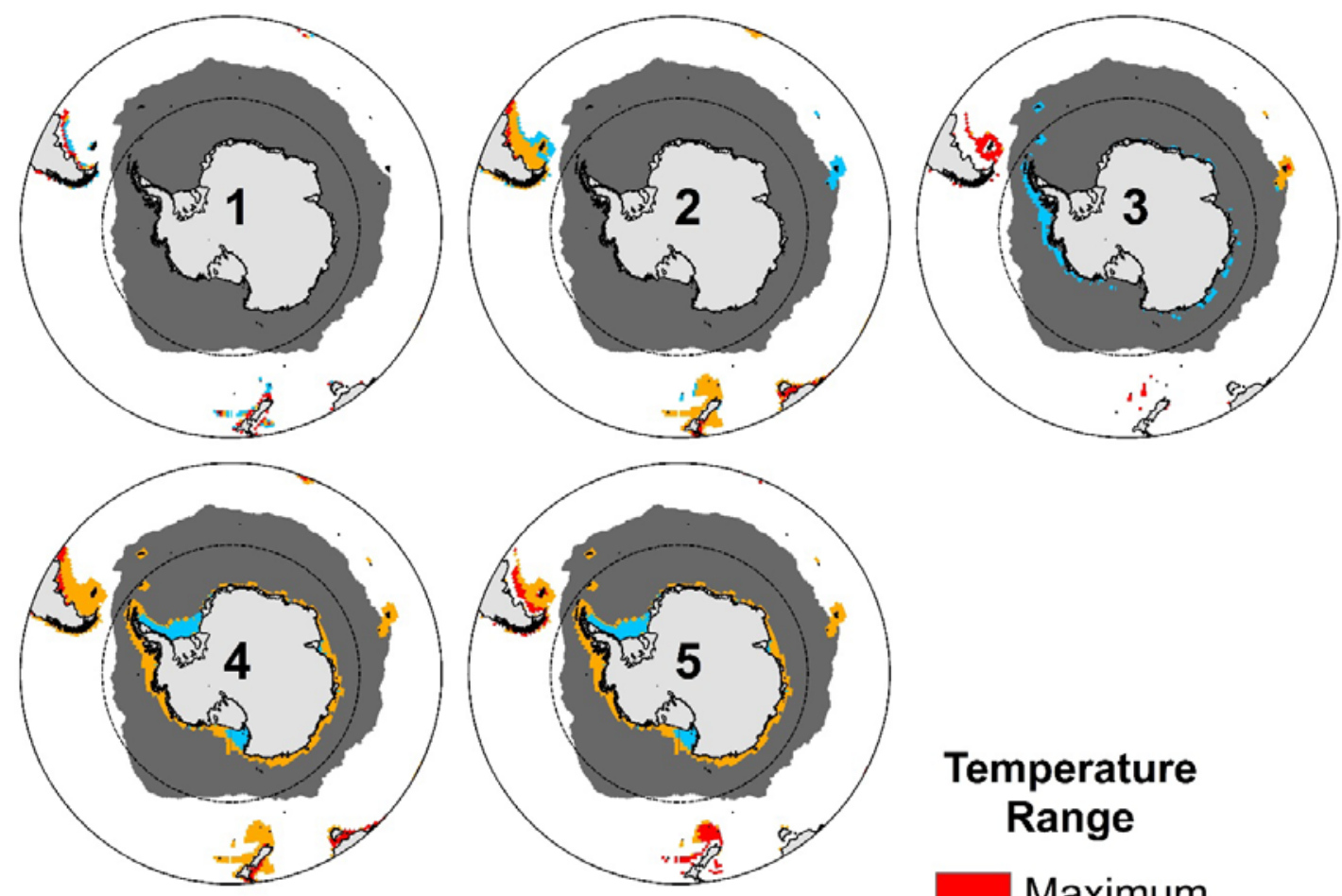

\section{Temperature Range}
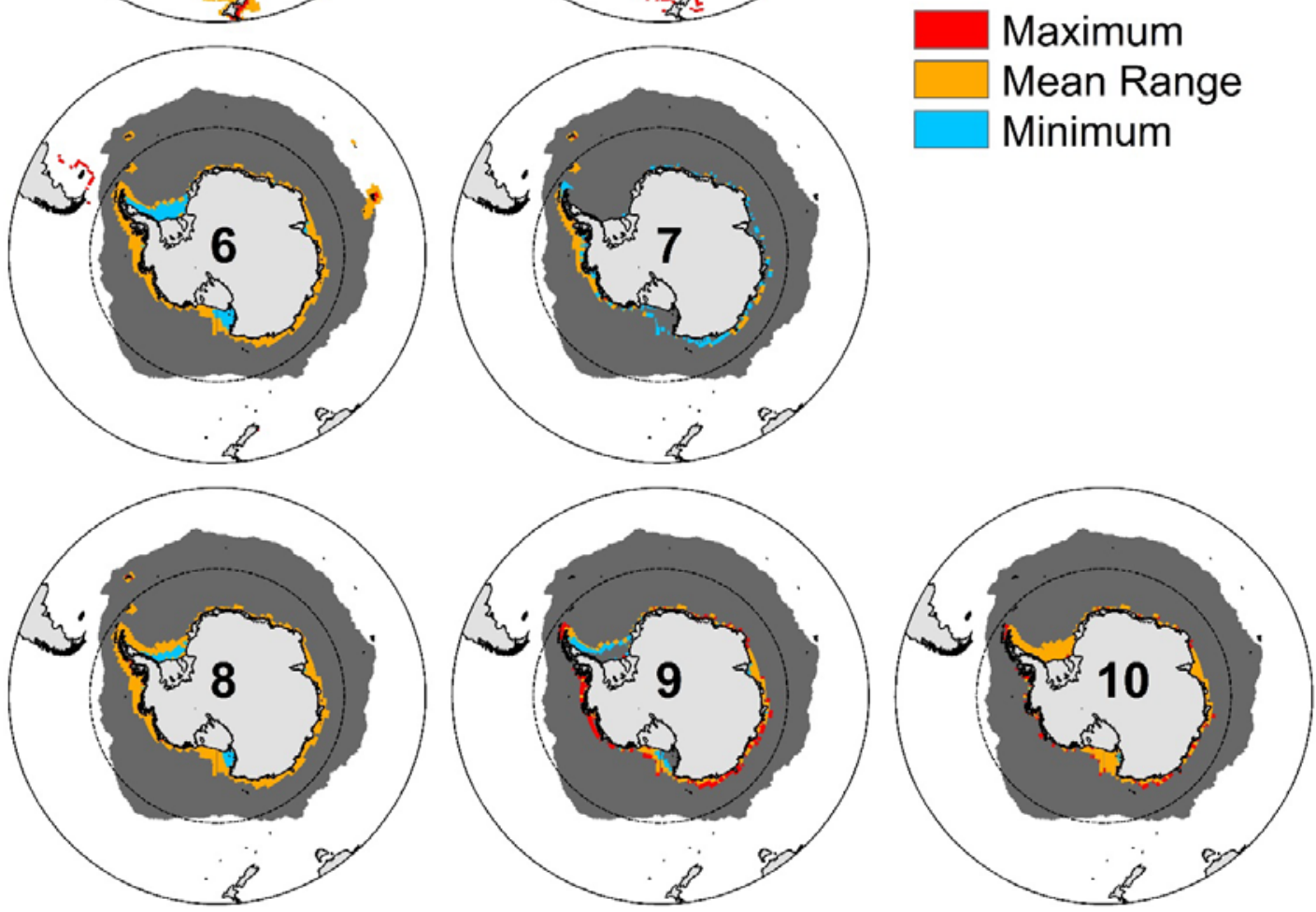

Supplementary Figure 1. Present-day potential range for groupings of seafloor invertebrates from south of $40^{\circ} \mathrm{S}$, grouped by $>80 \%$ similarity in their thermal distribution patterns. Groupings are those illustrated in Figure 2 and Supplementary Table 2. Dashed line is $60^{\circ} \mathrm{S}$, grey area is south of the Polar Front (as defined by Moore et al., 1999). 

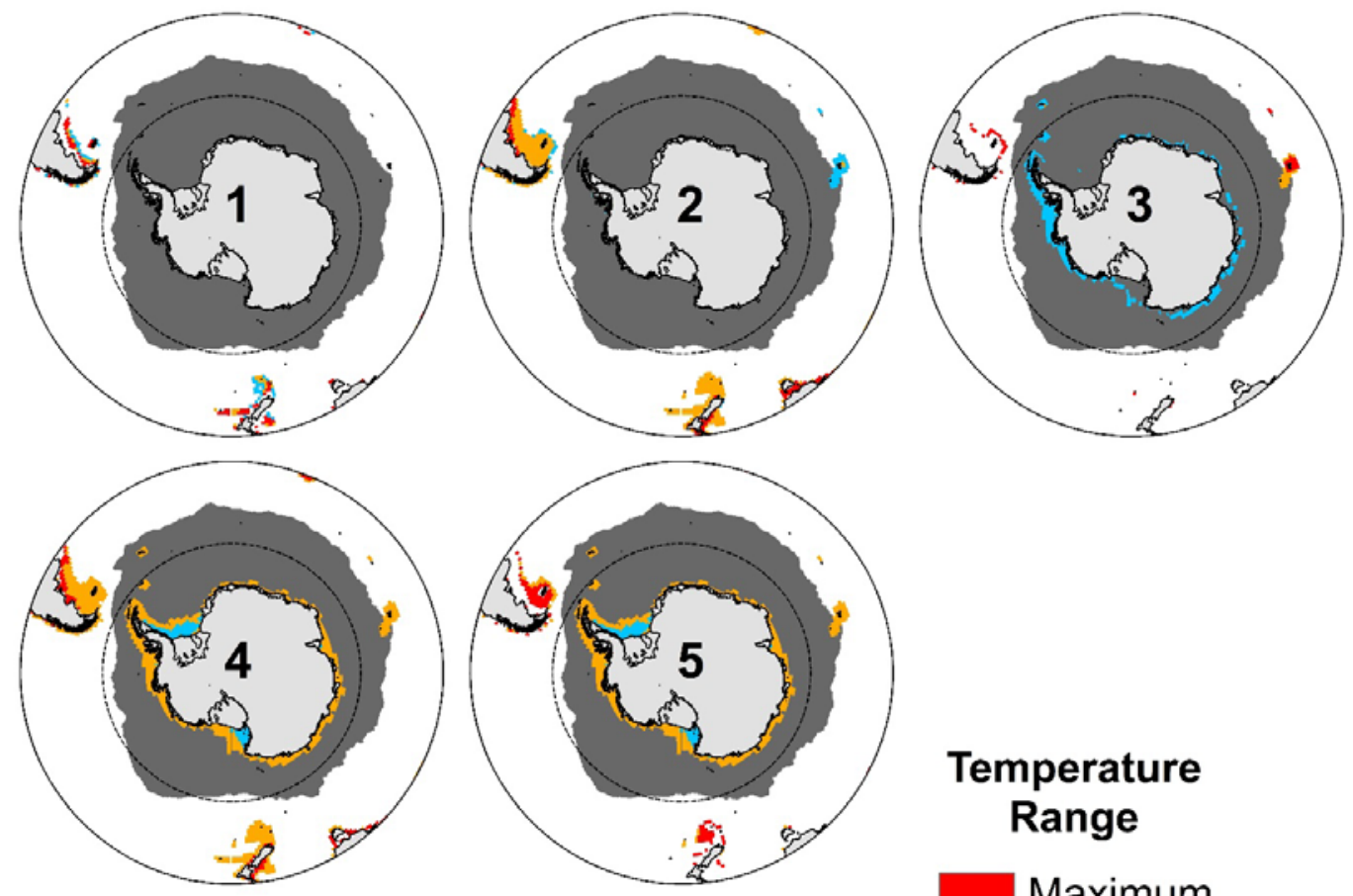

\section{Temperature Range}
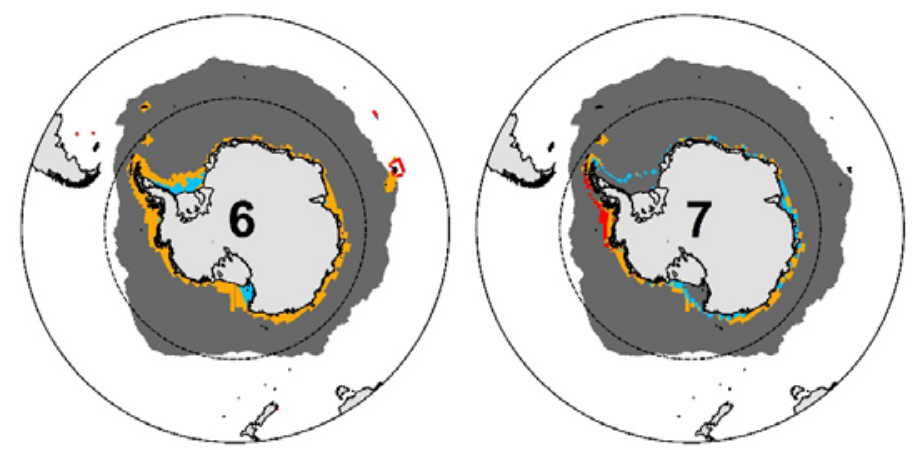

Maximum

Mean Range

Minimum
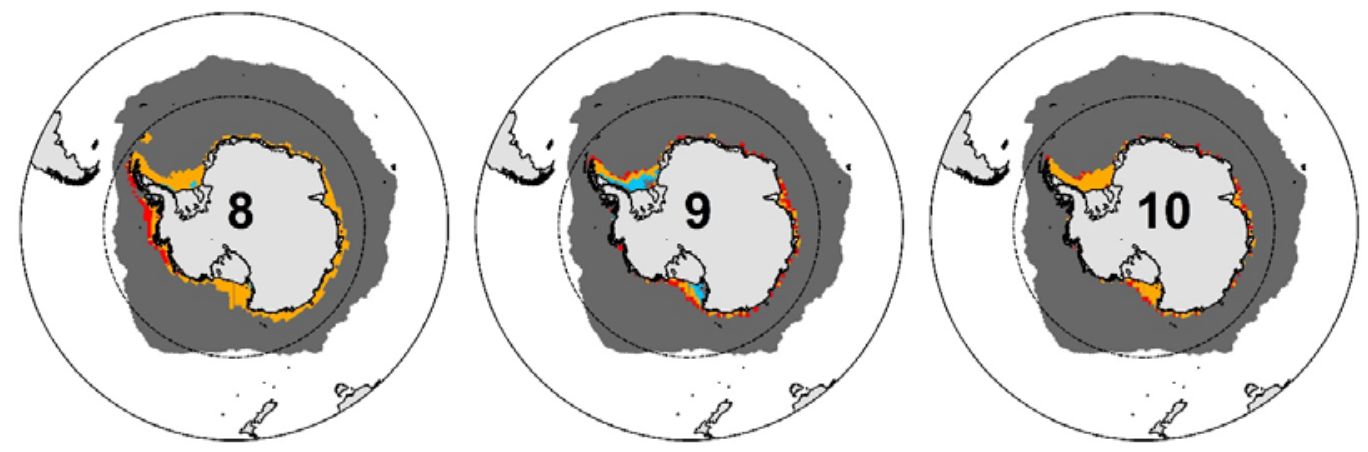

Supplementary Figure 2. 2099 potential range for each grouping of seafloor invertebrates from south of $40^{\circ} \mathrm{S}$, grouped by $>80 \%$ similarity in their thermal distribution patterns (based upon suitable present day temperature ranges, using RCP8.5 mean ensemble projections). Groupings are those explained in Figure 2 and Supplementary Table 2. Dashed line is $60^{\circ} \mathrm{S}$, grey area is south of the Polar Front (as defined by Moore et al., 1999). 


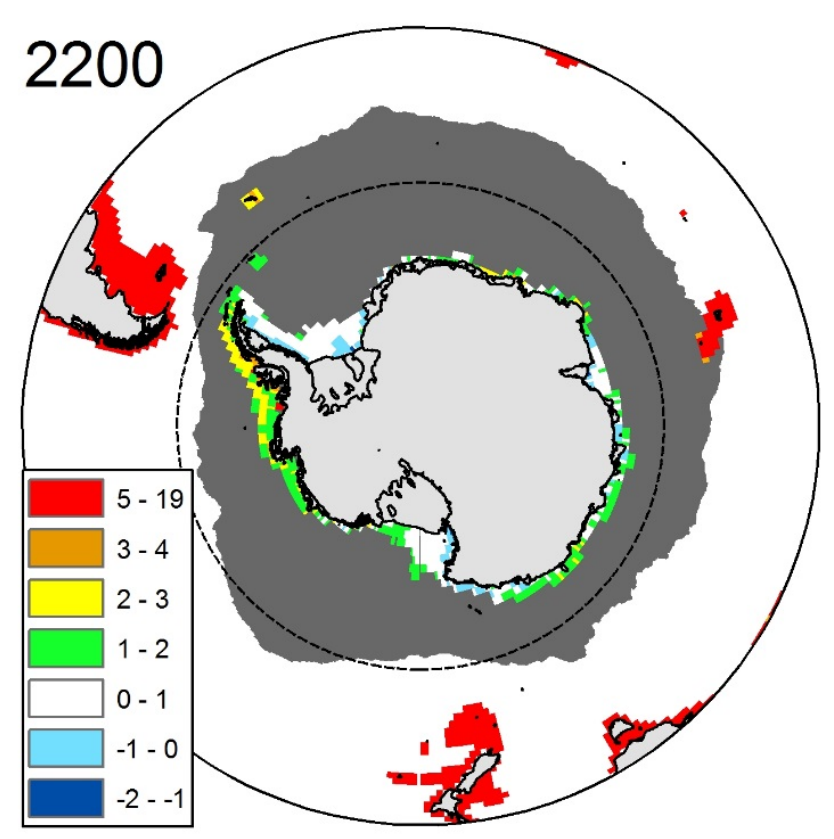

Supplementary Figure 3. Mean ensemble seafloor temperatures $\left({ }^{\circ} \mathrm{C}\right)$ for 2200 under RCP8.5projections. Dashed line is $60^{\circ} \mathrm{S}$, grey area is south of the Polar Front (as defined by Moore et al., 1999). 